Boston University School of Law Scholarly Commons at Boston University School of Law

Faculty Scholarship

Summer 2017

\title{
The Agency Problems of Institutional Investors
}

Scott Hirst

Boston University School of Law

Lucian A. Bebchuk

Alma Cohen

Follow this and additional works at: https://scholarship.law.bu.edu/faculty_scholarship

Part of the Law and Economics Commons

\section{Recommended Citation}

Scott Hirst, Lucian A. Bebchuk \& Alma Cohen, The Agency Problems of Institutional Investors, 31 Journal of Economic Perspectives 89 (2017).

Available at: https://scholarship.law.bu.edu/faculty_scholarship/340 
ISSN 1936-5349 (print)

ISSN 1936-5357 (online)

\section{HARVARD}

JOHN M. OLIN CENTER FOR LAW, ECONOMICS, AND BUSINESS

THE AGENCY PROBLEMS OF INSTITUTIONAL INVESTORS

Lucian A. Bebchuk

Alma Cohen

Scott Hirst

Discussion Paper No. 930

$08 / 2017$

As revised for publication in

Journal of Economic Perspectives, Vol. 31, 2017, pp. 89-102

Harvard Law School

Cambridge, MA 02138

This paper can be downloaded without charge from:

The Harvard John M. Olin Discussion Paper Series: http://www.law.harvard.edu/programs/olin_center

The Social Science Research Network Electronic Paper Collection:

https://papers.ssrn.com/abstract=2982617

This paper is also Discussion Paper 2017-11 of the Harvard Law School Program on Corporate Governance 


\begin{abstract}
We analyze how the rise of institutional investors has transformed the governance landscape. While corporate ownership is now concentrated in the hands of institutional investors that can exercise stewardship of those corporations that would be impossible for dispersed shareholders, the investment managers of these institutional investors have agency problems vis-à-vis their own investors. We develop an analytical framework for examining these agency problems and apply it to study several key types of investment managers.

We analyze how the investment managers of mutual funds - both index funds and actively managed funds - have incentives to underspend on stewardship and to side excessively with managers of corporations. We show that these incentives are especially acute for managers of index funds, and that the rise of such funds has system-wide adverse consequences for corporate governance. Activist hedge funds have substantially better incentives than managers of index funds or active mutual funds, but their activities do not provide a complete solution for the agency problems of institutional investors.

Our analysis provides a framework for future work on institutional investors and their agency problems, and generates insights on a wide range of policy questions. We discuss implications for disclosure by institutional investors; regulation of their fees; stewardship codes; the rise of index investing; proxy advisors; hedge funds; wolf pack activism; and the allocation of power between corporate managers and shareholders.
\end{abstract}

JEL Classification: G23; G34; K22

Keywords: Institutional investors, investment managers, mutual funds, index funds, hedge fund activism, stewardship 


\section{The Agency Problems of Institutional Investors}

\section{Lucian A. Bebchuk, Alma Cohen, and Scott Hirst}

$\mathbf{F}$ inancial economics and corporate governance have long focused on the agency problems between corporate managers and shareholders that result from the dispersion of ownership in large publicly traded corporations. In this paper, we focus on how the rise of institutional investors over the past several decades has transformed the corporate landscape and, in turn, the governance problems of the modern corporation. The rise of institutional investors has led to increased concentration of equity ownership, with most public corporations now having a substantial proportion of their shares held by a small number of institutional investors. At the same time, these institutions are controlled by investment managers, which have their own agency problems vis-à-vis their own beneficial investors. These agency problems are the focus of our analysis.

Lucian A. Bebchuk is the James Barr Ames Professor of Law, Economics, and Finance and the Director of the Program on Corporate Governance, both at Harvard Law School, Cambridge, Massachusetts. Alma Cohen is Professor of Empirical Practice at Harvard Law School and Associate Professor, Eitan Berglas School of Economics, Tel-Aviv University, TelAviv, Israel. Scott Hirst is Research Director of the Program on Institutional Investors and Lecturer on Law, both at Harvard Law School, Cambridge, Massachusetts. Bebchuk is a Research Associate and Cohen is a Faculty Fellow, National Bureau of Economic Research, Cambridge, Massachusetts. Their emails are bebchuk@law.harvard.edu, alcohen@law. harvard.edu, and shirst@law.harvard.edu.

${ }^{\dagger}$ For supplementary materials such as appendices, datasets, and author disclosure statements, see the article page at

https://doi.org/10.1257/jep.31.3.89

doi $=10.1257 /$ jep.31.3.89 
We develop an analytical framework for understanding the agency problems of institutional investors. We apply this framework to examine the agency problems and behavior of several key types of investment managers, including those that manage mutual funds-both index funds and actively managed funds-and activist hedge funds.

We identify several drivers of agency problems that afflict the decisions of investment managers of either passive index funds, active mutual funds, or both. First, such investment managers generally capture only a small fraction of the benefits that results from their stewardship activities while bearing the full cost of such activities. Further, competition with other investment managers is typically insufficient to eliminate these agency problems. Finally, investment managers may be further influenced by private incentives, such as their interest in obtaining business from corporations, that encourage them to side excessively with managers of corporations.

We show that index funds have especially poor incentives to engage in stewardship activities that could improve governance and increase value. Accordingly, while the rise of index funds benefits investors and the economy by reducing the costs of financial intermediation, this trend also has systemwide adverse consequences on governance.

Activist hedge funds have substantially better incentives than managers of index funds or active mutual funds. While their activities may partially compensate, we show that they do not provide a complete solution for the agency problems of other institutional investors.

We recognize that well-meaning investment managers of index funds and active mutual funds may sometimes make stewardship decisions that are superior to those suggested purely by their incentive calculus. Our focus, however, is on understanding the structural incentive problems that should be recognized in assessing the current governance landscape.

There is a growing recognition by researchers, capital market participants, and public officials that investment fund managers are imperfect agents for those investing in their funds, and there is now significant literature on this problem. Our analytical framework contributes by identifying the direction and manner in which the behavior of investment fund managers can be expected to deviate from the interests of their beneficial investors. For example, by demonstrating that the agency problems of institutional investors can be expected to lead them to underinvest in stewardship and side excessively with corporate managers, we show that concerns about the existence of such agency problems provide little basis for weakening shareholder rights or impeding shareholder action.

Furthermore, our analysis also generates insights on a wide range of policy questions and provides a framework for future work. We conclude by offering implications in a number of areas: disclosure by institutional investors and regulation of their fees; stewardship codes; the rise of index investing; proxy advisors; hedge fund and wolf pack activism; the allocation of power between corporate managers and shareholders; and others. 


\section{The Rise of Institutional Investors}

In their classic work on the separation of ownership and control, Berle and Means (1932) introduced the problem of publicly traded companies with widely dispersed ownership. In such situations, Berle and Means explained that, "[a]s his personal vote will count for little or nothing at the meeting ... the stockholder is practically reduced to the alternative of not voting at all or else of handing over his vote" to the proxy committee, appointed by existing management, who can "virtually dictate their own successors" (p. 87). Because dispersed shareholders can thus be expected to be rationally apathetic, managers will be relatively unconstrained in their actions, which Berle and Means refer to as "management control" of the corporation.

Furthermore, Berle and Means (1932) documented that a significant proportion of publicly traded corporations have a sufficiently broad dispersion of shareholders to be classified as management-controlled. For example, Berle and Means (pp. 107-109, table XII, panel G) show that, of the largest 200 corporations in 1930 that they listed as being controlled by hired managers (rather than run directly by owners), the aggregate percentage of the corporation's equity owned by the corporation's largest 20 shareholders had a mean of 10.55 percent (median of 10.6 percent).

Some classic articles by financial economists, following Berle and Means (1932), assume that shareholders of publicly traded firms are "atomistic" and have no incentive to seek governance improvements in the firms in which they own shares (for example, Grossman and Hart 1980; Shleifer and Vishny 1986). Given the practical infeasibility of such shareholder activities in the Berle-Means corporation, some researchers have focused on how other mechanisms, such as the discipline of the market for corporate control (Manne 1965), stock ownership by managers (Demsetz 1983), or price pressure due to sale of shares by investors seeking to exit underperforming companies (Admati and Pfleiderer 2009) could constrain the agency problems of managers and thereby make up for the lack of direct shareholder effort to improve governance.

Berle and Means (1932, p. 47) argued that "[d]ispersion in the ownership of separate enterprises appears to be inherent in the corporate system. It has already proceeded far, it is rapidly increasing, and appears to be an inevitable development." However, the trend toward dispersion has been reversed in subsequent decades by the rise of institutional investors. The rise of institutional investors has been driven by investor recognition of the value of low-cost diversification and encouraged by favorable regulatory and tax treatment. Whereas institutional investors held 6.1 percent of outstanding corporate equity in 1950 (Tonello and Rabimov 2010), they held 63 percent of outstanding public corporate equity in 2016 (Board of Governors of the Federal Reserve System 2016, p. 130). Furthermore, because institutional investors aggregate the assets of a vast number of individuals, each institutional investor can hold large positions in many publicly traded companies. 
Table 1

Institutional Ownership of the 20 Largest US Corporations

\begin{tabular}{|c|c|c|c|c|}
\hline & \multirow[b]{2}{*}{ Corporation } & \multicolumn{3}{|c|}{ Percentage owned by largest holders } \\
\hline & & Largest 5 & Largest 20 & Largest 50 \\
\hline 1. & Apple Inc. & $17.5 \%$ & $26.8 \%$ & $35.4 \%$ \\
\hline 2. & Microsoft Corp. & $20.5 \%$ & $33.1 \%$ & $43.2 \%$ \\
\hline 3. & Exxon Mobil Corp. & $17.8 \%$ & $27.1 \%$ & $35.2 \%$ \\
\hline 4. & Johnson \& Johnson & $19.0 \%$ & $30.3 \%$ & $40.5 \%$ \\
\hline 5. & General Electric Co. & $17.5 \%$ & $28.0 \%$ & $37.3 \%$ \\
\hline 6. & AT\&T Inc. & $19.0 \%$ & $28.8 \%$ & $37.4 \%$ \\
\hline 7. & Wells Fargo \& Co. & $24.9 \%$ & $40.2 \%$ & $51.0 \%$ \\
\hline 8. & Verizon Communications Inc. & $20.1 \%$ & $32.9 \%$ & $43.7 \%$ \\
\hline 9. & Procter \& Gamble Co. & $18.4 \%$ & $28.3 \%$ & $38.2 \%$ \\
\hline 10. & JPMorgan Chase \& Co. & $19.5 \%$ & $34.7 \%$ & $47.1 \%$ \\
\hline 11. & Pfizer Inc. & $18.7 \%$ & $32.1 \%$ & $45.1 \%$ \\
\hline 12. & Chevron Corp. & $21.6 \%$ & $33.9 \%$ & $43.6 \%$ \\
\hline 13. & Coca-Cola Co. & $26.6 \%$ & $39.9 \%$ & $48.6 \%$ \\
\hline 14. & Visa Inc. & $23.8 \%$ & $41.7 \%$ & $56.3 \%$ \\
\hline 15. & Home Depot Inc. & $24.4 \%$ & $37.4 \%$ & $49.1 \%$ \\
\hline 16. & Disney (Walt) Co. & $17.9 \%$ & $29.6 \%$ & $39.1 \%$ \\
\hline 17. & Merck \& Co. & $26.1 \%$ & $38.4 \%$ & $50.1 \%$ \\
\hline 18. & Philip Morris International & $24.8 \%$ & $40.9 \%$ & $52.1 \%$ \\
\hline 19. & Intel Corp. & $20.2 \%$ & $32.9 \%$ & $44.6 \%$ \\
\hline 20. & Cisco Systems Inc. & $18.8 \%$ & $32.2 \%$ & $45.7 \%$ \\
\hline \multicolumn{2}{|c|}{ Mean } & $20.8 \%$ & $33.4 \%$ & $44.2 \%$ \\
\hline \multicolumn{2}{|c|}{ Median } & $19.8 \%$ & $32.9 \%$ & $44.2 \%$ \\
\hline
\end{tabular}

Source: FactSet Ownership database (by FactSet Research Systems).

Note: The table shows the aggregate ownership of the largest holders of the largest 20 US corporations by market capitalization as of June 30, 2016, excluding controlled corporations.

As a result of the rise of institutional investors, the scenario of dispersed ownership described by Berle and Means (1932) no longer approximates reality, not even for the largest publicly traded corporations. Table 1 lists the largest 20 US corporations by market capitalization as of June 30, 2016 (excluding controlled corporations), and the aggregate percentage of the stock of each corporation owned by their largest 5,20 , and 50 institutional investors. ${ }^{1}$

As Table 1 shows, current share ownership is significantly more concentrated than the level described by Berle and Means (1932). Indeed, because the figures in Table 1 exclude large holdings by noninstitutional investors, they likely underestimate the degree to which shares are concentrated among investors with significant holdings. Even among the largest 20 corporations, the largest 20 institutional

\footnotetext{
${ }^{1}$ Investment advisers that manage multiple mutual funds generally have corporate governance staff that cast votes in the same way for each fund and undertake stewardship on behalf of each fund. Accordingly, for the purposes of these calculations, we group the shareholdings of the mutual funds managed by each investment manager as a single "institutional investor."
} 
investors in 2016 had mean ownership of 33.4 percent (and similar median ownership of 32.9 percent), more than three times the figure reported by Berle and Means (1932); in each of the 20 corporations, the largest 20 institutional investors own more than 25 percent. Furthermore, among these very large public corporations, the percentage owned by the largest 50 institutional investors has a mean of 44.2 percent (the median is also 44.2 percent). The increase in concentration is perhaps most vivid when looking at the aggregate percentage owned by the largest five shareholders, which has a mean of 20.8 percent (median of 19.8 percent) and is above 17 percent in each of the 20 largest US corporations.

Data from ISS Voting Analytics shows that the mean percentage of shares outstanding voted at the 2015 annual meetings of these corporations for the election of directors was 68.7 percent (median of 70.8 percent). The largest 50 institutional investors thus cast a substantial majority of the votes at these annual meetings.

Thus, large institutional shareholders hold sufficiently sizable positions in each large corporation to have a non-negligible effect on the outcomes of shareholder votes. Moreover, these shareholders recognize that many of their fellow shareholders are similarly non-atomistic. Of course, because the benefits of each shareholder's actions will be shared with fellow shareholders, it will still be privately optimal for each shareholder to underspend on stewardship. However, given the current concentrated ownership of publicly traded corporations, if each shareholder were solely investing its own money, it would no longer be rational for all shareholders to be rationally apathetic. On the contrary, given that some stewardship involves limited costs and can generate significant increases in value, it is likely to be privately optimal for some shareholders with significant holdings to undertake such activities.

As a result of these changes, the prospects for stewardship by shareholders are substantially better today than in Berle-Means corporations. Institutional investors participate in corporate voting, and there is empirical evidence that the presence of institutional investors influences how corporations are governed (for example, Hartzell and Starks 2003; Aghion, Van Reenen, and Zingales 2013). Institutional investors therefore provide constraints on agency problems in their portfolio companies that dispersed shareholders in Berle-Means corporations were unable to accomplish.

However, investment managers invest other people's money. Thus, the question arises whether their stewardship decisions would be the same as those that they would make if they were solely investing their own money. Below we analyze the agency problems that could lead these investment managers to deviate from the stewardship decisions that would be optimal for their beneficial investors. These agency problems limit the extent to which our corporate governance system is able to benefit from the increased concentration of shareholdings, and are a key impediment to improving the governance of publicly traded corporations. 


\section{Stewardship by Investment Managers}

\section{Investment Funds, Active and Passive}

By investment funds we refer to funds that pool together the assets of many individuals and entities and invest them in a diversified portfolio of securities. The category of investment funds includes open-end mutual funds, closed-end mutual funds, exchange-traded funds, and other similar funds. Most of these investment funds are technically "investment companies," as defined and regulated by the Investment Company Act of 1940. Given our emphasis on corporate governance, we naturally focus on funds that invest in equity securities. Investment funds are the most important category of institutional investors and represent most of the assets held by institutional investors.

Investment funds generally enter into contracts with organizations, referred to in US securities regulations as "investment advisers," to manage the porfolios of investment funds. We will refer to these organizations as "investment managers."

Investment funds focusing on equity securities can be categorized by their investing strategy into those that actively manage their portfolio and those that passively invest by matching their portfolio weightings of corporations to those of an underlying equity index. We refer to the latter, which include both open-end mutual funds and exchange-traded funds, as index funds. Most mutual fund managers operate a number of mutual funds, often referred to collectively as a "mutual fund family." While most mutual fund families include both actively managed funds and index funds, mutual fund families predominantly operate one or the other kind of investment fund.

The index fund market is dominated by three investment managers: BlackRock, Vanguard, and State Street Global Advisors (sometimes referred to as the "Big Three"). These investment managers have assets under management of $\$ 3.1$ trillion, $\$ 2.5$ trillion, and $\$ 1.9$ trillion, respectively (Diamond 2016). The largest investment managers of actively managed funds include Fidelity Investments and the Capital Group, both of which have more than $\$ 1$ trillion in assets under management.

We pay particular attention to index funds because their share of the market for managed investments has increased significantly in recent years, a trend that is expected to continue. The move towards index funds is driven by the growing recognition of their low costs and tax advantages, and the evidence that they outperform most actively managed equity mutual funds (French 2008). Passively managed funds increased from 1 percent of total fund assets in 1984 to 12.6 percent in 2006 (French 2008), and the move from active to passive funds has continued since then. From 2013 to 2016 , investors added $\$ 1.3$ trillion to passive mutual funds and exchange-traded funds (Tergesen and Zweig 2016).

The rise of index investing has benefits in reducing the costs of intermediation borne by investors; as of the end of 2015, the asset-weighted average net expense ratio was only 0.12 percent for US equity index funds, compared 
to 0.79 percent for actively managed US equity funds (Oey and West 2016, p. 6). We recognize this benefit to investors, but wish to stress a systemic cost of index funds. As we discuss below, while agency problems afflict the stewardship activities of all investment funds, they are likely to be especially acute for index funds.

\section{Stewardship}

Our focus is on those decisions of investment managers that relate to the stewardship of companies in their portfolio. Stewardship by investment managers can take several forms. Most investment funds are required to vote at shareholder meetings on director elections and management and shareholder proposals, and to have an internal process for making voting decisions. Thus, not voting, or voting in a patently uninformed manner, is not an option for investment managers. Stewardship therefore requires monitoring of corporate managers and other information gathering in order to inform voting, engagement, and other stewardship activities. Investment managers can nominate candidates for election as directors or put forward shareholder proposals, and they can communicate with the corporation, or with other shareholders, about such matters. While stewardship may also relate to environmental and social matters that affect investors (for example, Hirst 2016), our focus in this paper is on stewardship decisions that affect beneficial investors only through their effect on the financial value of the managed portfolio.

Stewardship decisions can be split into two parts: 1) spending decisions regarding how much to expend on stewardship; and 2) qualitative decisions regarding which way to vote or which positions to take in communications with corporate managers and other shareholders.

Like all organizations with multiple employees, investment managers have their own internal agency problems. Our analysis can be thought of as analyzing the incentives that would shape the stewardship strategies that the leaders of investment managers would pursue, for example, choices regarding the resources to provide for corporate governance and proxy voting units and setting the general policy and approach of such units.

Because the voting and stewardship decisions of mutual fund families are commonly concentrated in a single corporate governance department or proxy voting department of the investment manager, the stewardship incentives of investment managers with different types of funds are a composite of the different incentives we identify below for the different types of investment funds.

\section{Sources of Agency Problems}

\section{The Benchmark Scenario: Decisions that Maximize Portfolio Value}

Let us consider a hypothetical scenario with no agency problems in managing such investments. For instance, imagine that each of the positions were those of sole owners that owned and managed 100 percent of each investment. In this case, 
the decisions made would be ones that maximize the value of the owners' wealth. More specifically, suppose that some stewardship activity will cost $C$ and will increase the value of the position by $\Delta V$. Then, in the benchmark, no-agency scenario, the stewardship activity will be undertaken if $C<\Delta V$. $^{2}$

For large equity positions, like those that investment managers hold in many companies, the no-agency-costs scenario would often justify meaningful investments in stewardship activities. If an investor had a $\$ 1$ billion investment in a given portfolio company, and investment in certain stewardship activities would increase the value of the company by 0.1 percent, then the investor would have an incentive to spend up to $\$ 1$ million on stewardship to bring about this change. We note that each large mutual fund family holds positions exceeding $\$ 1$ billion in value in a large number of public companies; data from the FactSet Ownership database shows that, as of December 31, 2016, BlackRock, Capital Research, Fidelity, State Street Global Advisors, and Vanguard each held such positions at a substantial proportion of corporations in the S\&P 500 index.

In many cases, stewardship decisions may be merely qualitative, and not involve additional cost. This is commonly the case when investment managers decide how to cast a vote or what position to take in interactions with corporate managers or fellow shareholders. Suppose that voting or otherwise taking a position against the outcome management prefers would change the value of the position by $\Delta V$, where $\Delta V$ can be positive or negative. In such a case, in the no-agency-cost benchmark scenario, the investor should make a choice against managers' preferences whenever $\Delta V$ is positive.

\section{Capturing Only a Small Fraction of the Benefit}

We now turn to the decisions that the investment manager would find privately optimal. Although we will later relax these assumptions, we will initially take as given the size of fees charged by investment managers and the size of the portfolio managed.

One key source of agency problems is that investment managers bear the costs of stewardship activities, but capture only a small fraction of the benefits they create. Under existing regulations governing mutual funds, investment managers cannot charge their personnel and other management expenses directly to the portfolio. For example, if an investment manager were to employ staff fully dedicated to stewardship of a single corporation, or if an investment manager were to conduct a proxy fight in opposition to incumbent managers, it would have to cover those expenses itself, out of the fee income it receives from investors.

At the same time, the benefits from stewardship flow to the portfolio. Mutual fund managers and investment managers of other similarly structured funds are not permitted to collect incentive fees on increases in the value of their portfolio but

\footnotetext{
${ }^{2}$ In developing our analytical framework, we draw upon the model in Bebchuk and Neeman (2010), which explains how the decisions that institutional investors make with respect to lobbying regarding investor protection levels differ from the decisions that would be optimal for the beneficial investors in those funds.
} 
may only charge fees that are calculated as a percentage of assets under management. Let $\alpha$ be the fraction of assets under management that an investment manager charges as fees. Therefore, $\alpha$ is also fraction of the increase in the value of a portfolio company that an investment fund will be able to capture, in present value terms, from additional fees. The value of $\alpha$ is likely to be small given that the asset-weighted average net expense ratio for US equity index funds was 0.12 percent as of December 31, 2015 (Oey and West 2016). It would not be in the interests of the investment manager to spend an amount $C$ that would produce a gain of $\Delta V$ to the portfolio if $C$ is larger than $\alpha \times \Delta V$. Thus, in this setting, agency problems would lead to underspending on stewardship, precluding efficient expenditure, whenever:

$$
\alpha \times \Delta V<C<\Delta V
$$

To illustrate this wedge, reconsider the example above of an investment manager of an index fund that holds a $\$ 1$ billion investment in a portfolio company whose value could increase by $\$ 1$ million as a result of certain stewardship activities. If the investment manager could expect additional fees with a present value of 0.12 percent from the changes in the value of the position, it would be willing to take such actions only if their cost was below $\$ 1,200$, compared to $\$ 1$ million in the no-agency-costs scenario.

Although investment managers of actively managed funds charge higher fees, because those fees are still a very small fraction of the investment, they will have only slightly higher incentives to spend on stewardship. If such an investment manager received additional fees of 0.79 percent of the change in the value of the positionthe asset-weighted average net expense ratio for actively-managed US equity mutual funds as of December 31, 2015 (Oey and West 2016) — then it would be willing to take such actions only if their cost was below $\$ 7,900$. Thus, managers of active mutual funds still have strong incentives to spend much less on stewardship than would be value-maximizing for their portfolio.

\section{The Limits of Competition: Index Funds}

Thus far, our analysis has assumed that investment managers take their fees and assets under management as given when making stewardship decisions. By relaxing this assumption, we now consider whether the desire to improve performance and attract additional funds might counter the distortions identified above and lead investment managers to make additional investments in stewardship that would be portfolio-value-maximizing.

In examining this question, it is important to recognize that what matters for attracting assets under management (and thereby increasing future fee revenue) is not the absolute performance of the investment manager, but its performance relative to alternative investment opportunities. Potential investors in equity mutual funds can be expected to judge the investment manager's performance relative to an equity index, or relative to other comparable equity mutual funds. As a result, in 
many cases, the consideration of improving relative performance would not provide any incentives to improve stewardship decisions.

In particular, this is the situation in the important case of the investment managers of passively managed index mutual funds. If the investment manager of a certain mutual fund that invests according to a given index increases its spending on stewardship at a particular portfolio company and thereby increases the value of its investment in that company, it will also increase the value of the index, so its expenditure would not lead to any increase in the performance of the mutual fund relative to the index. Nor would it lead to any increase relative to the investment manager's rivals that follow the same index, as any increase in the value of the corporation would also be captured by all other mutual funds investing according to the index, even though they had not made any additional expenditure on stewardship.

Thus, if the investment manager were to take actions that increase the value of the portfolio company, and therefore also the portfolio that tracks the index, doing so would not result in a superior performance that could enable the manager to attract funds currently invested with rival investment managers. Such decisions would also not enable the investment manager to increase fees relative to rivals tracking the same index, as such rivals would offer the same gross return without the increased fees. Accordingly, for managers of index funds, a desire to improve relative performance would not provide any incentives that could counter tendencies that the investment manager might otherwise have to underspend on stewardship and to side with corporate managers more often than is optimal for the investment managers' beneficial investors.

It could be argued that the inability of index funds to attract additional investors by increasing stewardship spending implies that the existing equilibrium is optimal. However, our analysis indicates that this equilibrium is due to a collective action problem. The beneficial investors of an index fund would be better served by having the fund increase stewardship spending up to the level that would maximize the portfolio value, even if the fund increased its fees to fund this spending. However, if the index fund were to raise its fees and improve its stewardship, each individual investor in the fund would have an incentive to switch to rival index funds. That is, a move by any given index fund manager to improve stewardship and raise fees would unravel, because its investors would prefer to free-ride on the investment manager's efforts by switching to another investment fund that offers the same indexed portfolio but without stewardship or higher fees.

\section{The Limits of Competition: Actively Managed Funds}

Turning to actively managed funds, it is important to recognize that there is evidence that many of these funds are, to varying extents, "closet indexers" whose holdings substantially overlap with their benchmark index, deviating only by underweighting and overweighting certain stocks (Cremers and Petajisto 2009). For an actively managed fund that is to some extent a closet indexer, a desire to improve relative performance would provide no incentives to move stewardship decisions toward optimality for any of the portfolio companies where the company's 
weighting in the investment fund's portfolio is approximately equal to its weighting in the index; improving the value of those portfolio companies would not enhance performance relative to the index.

Furthermore, for all the corporations that are underweight in the portfolio relative to the index, enhancing the value of the corporation would actually worsen the investment manager's performance relative to the index. For corporations that are underweight in the portfolio, the consideration of increasing relative performance does not provide any incentive to enhance the value of these corporations; on the contrary, this consideration weighs against trying to do so.

Thus, the desire to improve relative performance could only provide an actively managed fund with incentives to improve value in those corporations that are overweight in the portfolio compared to the index. Even for such corporations, the extent to which improving the value of the corporation would improve fund performance will depend on the extent to which the corporation is overweight in the portfolio.

Consider a portfolio company that constitutes 1 percent of the benchmark index and 1.2 percent of the investment fund. In this case, any increase in the value of the portfolio company will be substantially shared by rival funds that track the index at least partly. Indeed, the increase in value of the portfolio company will worsen the performance of the investment fund relative to rival funds that are more overweight with respect to the portfolio company. Thus, even for companies that are overweight within the portfolio of the investment fund relative to the index, the impact of the desire to improve relative performance would be diluted by the presence of the company in the benchmark index and in the portfolios of rival funds.

Furthermore, as discussed above, in most cases actively managed funds are part of mutual fund families composed of a number of mutual funds, and stewardship decisions are commonly made for all these investment funds by the fund family's governance or proxy voting group. In such a case, the fact that a given actively managed fund is overweight in a particular corporation might be offset by the fact that other actively managed funds within the same fund family might be underweight. The investment manager of the fund family will have an incentive to bring about an increase in value only if its actively managed funds are on the whole overweight in this corporation, and the incentive will be diluted to the extent that any gains will be shared by other mutual fund families.

In addition, an interest in improving their relative performance might also push investment managers in the opposite direction, and thereby exacerbate rather than alleviate distortions in stewardship decisions. Ke, Petroni, and Yu (2008, p. 855) describe evidence that some institutional investors value "direct access to companies' management," presumably because they believe that, notwithstanding the limitations imposed by Regulation Fair Disclosure, being able to communicate with managers will improve their trading decisions. For investment managers following active strategies, trading decisions that change the weight of a portfolio company relative to its weighting in the index are likely to be the main determinants of their performance relative to their benchmark index. To the extent that active 
investment managers believe that making stewardship decisions that corporate managers disfavor might adversely affect their access to such managers, an interest in improving relative performance could provide incentives to avoid such decisions.

Note that, to the extent that investment managers get access to corporate managers and consequently make better trading decisions, the gains from such trading decisions will improve the investment manager's performance relative to others, since rivals will not share these trading gains. By comparison, gains from governance-generated improvements in the value of particular portfolio companies will be substantially shared with rivals. Thus, an interest in improving relative performance could well lead active fund managers to place more weight on gains to their portfolios from access to corporate managers relative to gains from governance-generated increases in value, compared to what would be optimal for the investment funds' beneficial investors. ${ }^{3}$

Finally, without discussing the issue in detail, we want to flag a disagreement in the literature regarding the extent to which fund inflows and outflows are sensitive to changes in relative performance (for example, Sirri and Tufano 1998 and Coates and Hubbard 2007). To the extent that the sensitivity of inflows and outflows to performance is limited, competition with other investment funds will give investment managers limited incentives to improve the value of portfolio companies.

\section{The Governance Passivity of Investment Funds}

The above analysis suggests that investment managers, those managing both passive index funds and active mutual funds, have incentives to be "more passive" with respect to governance issues than is optimal for their beneficial investors.

With respect to index funds, our analysis is consistent with the practically negligible resources that index funds spend on stewardship beyond what is required to comply with regulations requiring investment managers to vote shares in portfolio companies and to avoid doing so in an uninformed fashion. Vanguard employs about 15 staff for voting and stewardship at its 13,000 portfolio companies; BlackRock employs 24 staff for voting and stewardship at 14,000 portfolio companies; and State Street Global Advisors employs fewer than 10 staff for voting and stewardship at 9,000 portfolio companies (Krouse, Benoit, and McGinty 2016).

Of course, these staff may receive information from proxy advisors as well as from active portfolio managers employed by the investment manager. However, each of these major investment managers devotes less than one person-workday per year, on average, to assessing this and other information, and undertaking other stewardship activities with respect to each of their portfolio companies. Note that each of these investment managers is likely to hold several percent of each company's stock and to be among their largest shareholders. Given the size and value of the positions

\footnotetext{
${ }^{3}$ An increase in relative gross returns could be used by an investment manager not to attract additional funds but to extract an increase in the level of fees charged without risking an outflow of funds. The above analysis, suggesting that an interest in increasing relative performance is unlikely to induce optimal stewardship decisions, also applies equally to this scenario.
} 
that each of these investment managers holds in large public companies, there are grounds for concern that these managers substantially underinvest in stewardship.

With respect to active mutual funds, our analysis is similarly consistent with the very limited resources that predominantly actively managed mutual fund families currently spend on stewardship. Even the largest such mutual fund families employ only a small number of staff to make voting decisions and undertake all other governance-related stewardship activities in the vast number of corporations in which they hold stock.

In a companion paper, we document that this underinvestment by investment managers is reflected not only in the limited time that their staff spend on voting and stewardship activities, but also in the absence of these investment managers from the ranks of investors that use certain significant tools to generate value increases from improved governance that benefit the investment funds (Bebchuk, Cohen, and Hirst 2017). For example, large investment managers generally avoid submitting shareholder proposals, nominating directors to the boards of corporations, or conducting proxy contests. Their absence might be due not only to incentives to underspend on stewardship, but also to private costs that investment managers viewed as oppositional to managers might have to bear, which we discuss below.

Our companion paper also addresses the argument that substantial passivity on the part of investment managers is optimal, and that the underspending problem is therefore of limited economic importance. Such an argument could be justified if other mechanisms-such as the discipline of the market for corporate control, executive incentives schemes, or monitoring and engagement by other investors-could be relied on to eliminate agency problems in public companies. We argue, however, that the limits of such mechanisms make it plausible to assume that improved stewardship by the investment managers that hold a large proportion of the shares of most publicly traded companies can significantly improve outcomes for their own investors.

There is a growing recognition of the power of large investment managers, and concomitantly increasing expectation that they will use this power to improve the governance of their portfolio companies. The leaders of the largest index fund managers have responded by making public announcements stressing their commitment to stewardship, and to improving corporate governance (for example, Fink 2015; McNabb 2015). These executives may indeed believe in the desirability of governance improvements and sincerely wish to help bring them about. However, our economic analysis indicates that investment managers may well have very limited economic incentives to spend on stewardship, and may have economic incentives to be more lax toward corporate managers, compared with what would be optimal for their beneficial investors.

\section{Private Costs from Opposing Managers}

Another significant source of agency problems introduced by the separation between investment managers and beneficial owners is that investment managers may bear private costs from taking positions that corporate managers disfavor. When 
such private costs may result, investment managers may be more reluctant to spend on actions or make qualitative decisions that are disfavored by corporate managers. Suppose that such an action would result in a change in the value of the portfolio of $\Delta V$ but a private indirect cost of $I C$ to the investment manager. The investment manager will take the disfavored action only if $C+I C$ is less than $\alpha \times \Delta V$.

For qualitative choices that would not involve any additional marginal cost but would have an expected positive effect on the value of the portfolio (that is, $\Delta V>0$ ), the investment manager would prefer to side with managers if $I C>\alpha \times \Delta V$. Thus, the investment manager would prefer to avoid taking a position disfavored by managers that would be optimal for the managed portfolio if and only if:

$$
0<\Delta V<\frac{I C}{\alpha}
$$

What is important is not whether avoiding such actions actually helps investment managers obtain business, but whether investment managers believe that to be the case, on an expected value basis. The smaller is $\alpha$, the wider the range of increases in value that the investment manager would forgo not to bear expected indirect costs of taking actions that corporate managers disfavor. That investment funds charge fees below 1 percent (on average) strengthens the distortion resulting from potential indirect costs.

One important source of costs from taking positions that corporate managers disfavor (or benefits from taking positions that managers favor) comes from the incentives of investment managers to obtain or retain business from public corporations. In 2015, 401(k) assets under management totaled $\$ 4.7$ trillion, with 60 percent held in mutual funds (Collins, Holden, Duvall, and Chism 2016, p. 2); most of these assets are likely to come from public corporations. Cvijanović, Dasgupta, and Zachariadis (2016) document that an average of 14 percent of fund family revenue is derived from $401(\mathrm{k})$-related business. The largest index fund managers and active managers all derive business from $401(\mathrm{k})$ services, and therefore have strong incentives to attract and retain such business from public corporations.

In addition, many investment managers provide investment services to corporations, both to manage cash and short-term investments and also to manage the long-term investments of financial corporations such as insurance companies. Investment managers may also provide investment management services to pension funds that are sponsored by public corporations, and over which the corporation may have some influence. US private sector pension funds had aggregate assets under management of \$2.9 trillion in 2015 (Investment Company Institute 2016). Several empirical studies provide evidence suggesting that business ties with corporations influence the voting decisions of investment managers. Davis and Kim (2007) find that the volume of pension fund business of investment managers was associated with those investment managers voting more often with corporate managers on several key types of shareholder proposals. Ashraf, Jayaraman, and Ryan (2012) find that mutual fund families that have greater business ties to corporations tend to vote 
more favorably toward corporate managers on executive compensation matters at all corporations.

These studies focus on the association between corporate business ties in general and voting in corporations in general. Cvijanović, Dasgupta, and Zachariadis (2016) examine contested shareholder proposals where corporate managers care more about votes for their favored position, and find that mutual fund families with business ties to a corporation are more likely to cast pro-management votes in closely contested situations at the corporation. Although this study provides evidence that an investment manager's business ties with particular corporations provide incentives to vote with corporate managers in close votes, there are clear limits to the ability of investment managers to treat managers of client corporations more favorably than their general voting policy would provide. Therefore, in our view, the more important concern is that investment managers will have an incentive to lean in a pro-management direction when determining their strategies and policies regarding stewardship.

Given the limited economic incentive that investment managers have to generate governance gains in portfolio companies, and their strong economic interest in attracting more business, choosing a pro-management approach within the range of the legitimate choices available to them may seem the safest approach to investment managers. Investment managers would have an incentive to take such an approach as long as they believe that doing so might help them get additional business from public corporations on an expected value basis.

Finally, we note certain additional private costs that are relevant only to the largest investment managers and may contribute to discouraging these major players from opposing corporate managers. Some mutual fund families hold close to or above 5 percent of the stock in many public corporations. Indeed, the three index fund managers that dominate the index fund sector-Vanguard, BlackRock, and State Street Global Advisors-hold such positions in most large publicly traded corporations; Fidelity Investments and the Capital Group also hold such positions in many public corporations, and Dimensional Fund Advisors holds such positions in many smaller public corporations. Investment managers holding such positions would bear additional private costs in the event that they attempt to wield significant influence-and therefore have a significant incentive to avoid doing so.

Under Section 13(d) of the Exchange Act of 1934, investors that own or control, in the aggregate, 5 percent or more of a corporation's shares and that seek to influence the control of the corporation are subject to extensive and repeated disclosure requirements on Schedule 13D. Nominating directors, undertaking a proxy contest for board representation, and other significant engagement action would classify investment managers as seeking to influence control. By contrast, investment managers that are not classified as seeking to influence control are subject only to the relatively limited disclosure requirements on Schedule 13G. Becoming subject to the substantial and repeated disclosure on Schedule 13D would be very costly for the investment managers of major fund families, which 
typically manage multiple funds. Because the investment manager would have to bear these costs itself rather than charge them to the investment funds, the prospect of having to bear such costs provides additional incentives to avoid taking any actions that might be classified as seeking to influence the control of the corporation.

\section{Activist Hedge Funds}

Finally, we would like to discuss a different type of an investment manager, the activist hedge fund manager. Applying the framework described above shows why activist hedge fund managers suffer less from the agency problems that affect investment managers with diversified equity portfolios, and why activist hedge fund managers have incentives to make stewardship decisions that are significantly closer to those that would be optimal for their beneficial investors.

\section{Why Activist Hedge Funds are Different}

Hedge funds managers limit their investment offerings to investors considered to be sophisticated, and are therefore not subject to the regulations governing investment managers of mutual funds. Hedge funds therefore have considerably more freedom in the assets they own, their use of leverage, and their compensation structures. Our focus below is on the subset of hedge funds that take concentrated positions in the equity of public corporations and actively engage with corporate managers-activist hedge funds. For the reasons explained below, these hedge funds have significant influence on the corporate governance landscape.

High-Powered Incentives to Increase Value. Hedge fund managers, including activist hedge fund managers, typically receive compensation based on two components, often referred to as "2 and 20" (French 2008): a management fee that is a relatively small percentage of the value of the assets, historically 2 percent, and an incentive payment, structured as a "carried interest" of a proportion (historically 20 percent) of any increase in value of the portfolio.

Leaving aside the management fee, which is higher than the average for an actively managed mutual fund but a similar order of magnitude, a hedge fund manager that is able to increase the value of a position in a portfolio company through investments in stewardship will capture 20 percent of this increase, an order of magnitude more than the percentage of any value increase that a mutual fund manager would be able to capture. Thus, activist hedge fund managers will have much stronger incentives to bring about governance-generated increases in value than investment managers of mutual funds, even when the latter hold positions with equal or greater dollar value.

Limited Business from Portfolio Companies. In contrast to mutual funds, which are registered investment companies and publicly issue securities, hedge funds are not registered investment companies and do not accept investments from 401 (k) plans. Accordingly, activist hedge fund managers do not have a desire to attract 
401(k) business that might discourage them from taking positions that corporate managers disfavor. In addition, activist hedge funds do not offer other services to corporations of the kind that many investment managers offer.

Concentrated Positions and Stronger Incentives Regarding Relative Performance. Activist hedge funds have concentrated positions, sometimes holding significant positions in as few as 10 portfolio companies. As a result, an improvement in the value of a single portfolio company that is a target of stewardship activities can substantially improve the fund manager's performance relative to peer investment vehicles. This will, in turn, affect the manager's ability to attract additional investments. For example, the investment of Pershing Square Capital Management LP in Canadian Pacific Railway Ltd. and General Growth Properties Inc. each constituted as much as one-fifth of the fund's portfolio during certain periods, and the increase in the value of these positions enabled the fund to post strong performance.

Because of their small size and method of selection, activist hedge fund portfolios display very little correlation with those of competing funds, or with other investment opportunities available to their investors. Any changes in the value of their portfolio companies are therefore also clearly reflected in their relative performance against such comparable investments. This factor therefore strengthens the incentive of activist hedge fund managers to bring about governance-related improvements in the value of their portfolio companies. Thus, the desire to improve relative performance provides more powerful incentives for activist hedge funds to seek governance-related value improvements than it does for managers of index funds and active mutual funds.

Clearly, the main factors that create a wedge between the interests of investment managers and the beneficial investors whose investments they manage affects activist hedge fund managers significantly less than investment managers of mutual funds. Consistent with this, activist hedge fund managers are much more willing to devote significant resources to stewardship. Activist hedge fund managers are often willing to devote hundreds of person-hours per year to monitoring and engaging with each of their portfolio companies. For instance, Pershing Square Capital Management has an investment team of eight, plus several other employees, that oversee a portfolio of about 12 corporations (as reported in Krouse, Benoit, and McGinty 2016). Activist hedge fund managers are also willing to have representatives on the board of directors of portfolio companies, and often seek such representation. Such representation not only requires significant personnel time, but also imposes constraints on the activist hedge fund manager's trading in the portfolio company's stock.

Furthermore, activist hedge fund managers frequently commence proxy contests at portfolio companies (Brav, Jiang, Partnoy, and Thomas 2008), despite the considerable expenses associated with such contests (estimated by Gantchev 2013 to average about $\$ 10$ million) and corporate managers' views of such contests as adversarial. By contrast, managers of mutual funds have generally avoided conducting proxy contests at their portfolio companies, even where the mutual fund held a significant stake. Even in situations where activist hedge fund managers do not conduct proxy contests, they frequently take public positions that the managers of their portfolio companies disfavor, which other investment managers generally avoid. 
Clearly activist hedge fund managers have different incentive structures that enable them to play an important role in the current governance landscape. This role is especially important in light of the significant agency problems that afflict the stewardship decisions of mutual fund managers. But while activist hedge fund managers play a beneficial role in the corporate governance system, there are significant limits to this beneficial role.

\section{The Limits of Hedge Funds}

Activist hedge fund managers have incentives to spend on stewardship only when the governance-generated value increases likely to result are especially large. The incentives of activist hedge fund managers are driven by the significant performance-related fees that they earn, and by their concentrated portfolios. As a result, activist hedge fund managers can pursue only those corporations where the potential governance-related increases in value are sufficiently large that the funds' investors can expect to make reasonable risk-adjusted returns after bearing the high fees charged by the hedge fund managers and the firm-specific risks from the funds' concentrated portfolios. For example, where an activist hedge fund could buy a stake in a given corporation and bring about a 3 percent increase in value over a two-year period, the hedge fund manager would be unlikely to pursue this opportunity.

This analysis is consistent with the fact that such funds usually focus on situations where governance failures have led to substantial operating underperformance. As a result, disclosures regarding the initiation of engagements by activist hedge fund managers are accompanied by abnormal returns that, on average, exceed 5 percent, reflecting market expectations of a significant expected increase in value (for example, Brav et al. 2008; Bebchuk, Brav, and Jiang 2015).

Furthermore, for an activist hedge fund manager to bring about a governancegenerated increase in value, it is not only necessary that there be potential for such a large increase, but also that other institutional investors are willing to support the changes sought by the activist hedge fund manager. Activist hedge fund managers are unable to bring about changes unless they obtain the support of other types of institutional investors, or have a reasonable likelihood of doing so (Bebchuk and Jackson 2012). When an activist hedge fund manager enjoys such support for the changes it seeks, it will be able to win a proxy fight, or obtain a settlement by credibly threatening to do so, and thereby cause the corporation to make such changes. Conversely, when corporate managers expect that most institutional investors will side with them and not with activist hedge fund managers, activist hedge fund managers will not have much influence.

Mutual fund managers do sometimes vote on the side of activist hedge fund managers. Indeed, the expectation that this would be the case, and that activist hedge funds could therefore prevail in potential proxy fights, often leads corporate managers to accept activist hedge funds' demands for board representation (Bebchuk, Brav, Jiang, and Keusch 2017). However, our analytical framework raises the concern that, on the margin, mutual fund managers might not be sufficiently 
willing to support activist hedge fund managers in their engagements with portfolio companies where such support would be optimal for the mutual funds' investors. Whether and to what extent this is the case is an interesting issue for future research.

Finally, we should briefly note the issue of short-termism and long-termism. Activist hedge fund managers have stronger incentives to bring about increases in value than other institutional investors. However, some scholars have argued that activist hedge fund managers focus on increases in short-term value and that the increases they seek often come at the expense of long-term value (for example, Strine 2014; Coffee and Palia 2015). One of us has addressed this claim in detail elsewhere on both conceptual and empirical grounds (Bebchuk 2013; Bebchuk, Brav, and Jiang 2015). Leaving aside the alleged distinction between short-term and long-term increases in value, a key point of our analysis is that activist hedge fund managers stand out relative to other institutional investors in terms of their incentives to seek increased value.

Of course, index funds are long-term players, and can therefore be expected to favor only changes that would enhance value in the long term (for examples of this view, see Lipton 2014, 2016). But our analysis shows that investment managers overseeing index funds have very limited incentives to bring about governancegenerated increases in value, be they long-term or short-term.

\section{Implications}

The rise of institutional investors has transformed the governance landscape facing the modern corporation. With shares concentrated in the hands of institutional investors, corporate managers no longer face diffuse shareholders that are powerless to engage with managers. However, the agency problems of institutional investors prevent the full realization of the potential benefits of the increased concentration of shareholdings. Investment managers overseeing diversified equity portfolios have incentives to spend considerably less on stewardship, and to side with corporate managers more frequently, than would be optimal for their beneficial investors. These factors operate to suppress investor stewardship relative to optimal levels.

In this paper, we have provided a framework for analyzing these agency problems. We have also applied this framework to several key categories of investment managers. Our analysis has significant implications for researchers and policymakers. While a full analysis of these implications is beyond the scope of this paper, we outline ten of these implications below.

1. Research. Over recent decades, the amount of academic work analyzing agency problems in corporate governance has increased dramatically (for example, Bebchuk, Cohen, and Wang 2013), but most of this work has examined the agency problems of corporate insiders. We hope that our work will stimulate and provide a framework for future work on the agency problems of institutional investors. 
2. Disclosure. Public awareness and academic research about the agency problems of managers of publicly traded corporations is facilitated by the extensive disclosures made by such corporations about internal decisions. Policymakers may wish to consider adopting regulations that would require investment managers to disclose information that would enable investors and others to identify and assess agency problems. For example, investment managers of mutual funds have been required to disclose how they vote their shares in publicly traded corporations since 2004, but some other investment managers are not required to do so. Furthermore, policymakers may want to consider tighter disclosure requirements that would provide comprehensive information about the business ties between investment managers and the public corporations in which they invest.

3. Regulation of Mutual Fund Fees. Regulations that preclude key investment managers from charging stewardship expenses to their investment funds, or from tying fees to increases in the value of their portfolios, have significant effects on the stewardship decisions of these investment managers. These regulations might be justified to protect the beneficial investors in these investment funds. However, policymakers should recognize the tradeoffs created by these rules, and consider whether some adjustments may be warranted.

4. Stewardship Codes. In a number of countries, such as the United Kingdom (Financial Reporting Council 2012), Japan (Council of Experts Concerning the Japanese Version of the Stewardship Code 2014), and Canada (Office of the Superintendent of Financial Institutions Canada 2013), concerns about whether institutional investors undertake adequate stewardship have led to the development of nonbinding stewardships codes which various institutional investors have pledged to follow. Our analysis suggests that there is a problem with the incentives of institutional investors to spend on stewardship. To the extent that this is the case, stewardship codes putting forward aspirations, principles, or guidelines are likely to have less of an impact than if investment managers had appropriate incentives.

5. Index Investing. The rise of index investing has generally been viewed as a positive development because it has reduced the cost of investment intermediation. Our analysis shows that a continuation of this trend could have significant costs for corporate governance. This analysis also highlights the challenges likely to result if index funds continue to grow as expected.

6. Anticompetitive Effects of Index Investing. Recent work has raised concerns that, because index funds are invested across various corporations in an economic sector, they would have incentives to encourage those corporations to engage in anticompetitive behavior that would enable them to capture monopolistic rents, (for example, Elhauge 2016; Posner, Scott Morton, and Weyl 2016)..$^{4}$ This line of work is based on the premise that index fund managers have strong incentives to take whatever actions would maximize the collective wealth of their beneficial investors. Our analysis indicates that index fund managers might well have different incentives,

\footnotetext{
${ }^{4}$ These arguments build on empirical studies by Azar, Schmalz, and Tecu (2017) and Azar, Raina, and Schmalz (2016), although these studies have recently been questioned by Rock and Rubinfeld (2017).
} 
which would lead them to limit intervention with their portfolio companies. Thus, our analysis suggests that it is implausible to expect that index fund managers would seek to facilitate significant anticompetitive behavior.

7. Proxy Advisors. Institutional investors commonly employ the services of one or more proxy advisors, such as ISS and Glass Lewis, which analyze voting choices faced by investors in public corporations and make recommendations (Malenko and Shen 2016). Critics of proxy advisors would prefer that institutional investors reduce their reliance on the analysis and recommendations provided by proxy advisors (Clark and Van Buren 2013). Indeed, legislation currently being considered by Congress (previously titled the Proxy Advisory Firm Reform Act of 2016) would regulate proxy advisors in ways that might significantly increase their costs of operation and otherwise discourage their activities. Our analysis raises a concern that a reduction in the activities of proxy advisors would not be offset by increased spending on analysis by institutional investors sufficient to maintain even their current levels of monitoring.

8. Hedge Fund Activism. There is a heated debate over the role of hedge fund activism. Whereas some writers, including one of us, have been supportive of such activism (for example, Bebchuk and Jackson 2012; Bebchuk 2013; Bebchuk, Brav, and Jiang 2015; Gilson and Gordon 2013), others view it as counterproductive and advocate various measures that would limit and discourage such activism (for example, Strine 2014; Coffee and Palia 2015). Some prominent critics of hedge fund activism would like to see the engagement currently conducted by activist hedge fund managers replaced by the stewardship of institutional investors. Our analysis shows the important role that activist hedge fund managers play in the corporate governance landscape. Because the incentives of mutual fund managers differ substantially from those of activist hedge fund managers, were the abilities of hedge funds to undertake such engagement to be impeded, stewardship by mutual fund managers would be unlikely to replace activist hedge fund managers in constraining agency problems in public corporations.

9. Wolf Packs. When an activist hedge fund takes a position in an underperforming public corporation, other hedge funds often acquire positions in the corporation (Brav, Dasgupta, and Mathews 2016). Groups of such "follower" hedge funds are commonly referred to as "wolf packs," and various writers have suggested that they are a negative influence (for example, Coffee and Palia 2015). Our analysis, however, indicates that so-called wolf packs might serve a useful purpose. Because mutual funds might be reluctant to vote against incumbents, an activist hedge fund might sometimes be unable to win a proxy fight against underperforming incumbents when such victory would be in the interests of investors. By contrast, when a dispute between incumbents and an activist hedge fund draws other hedge funds to invest, the new shareholders are more willing to also invest in assessing which course of action would be optimal and to vote accordingly, including voting against the incumbents if they conclude it to be value-enhancing.

10. Shareholder Rights. For some critics of shareholder rights (Bainbridge 2006, for example), the imperfections of institutional investors, and the fact that 
stewardship decisions are taken by agents rather than the ultimate beneficial investors, provide a rationale for weakening shareholder rights and insulating corporate managers from shareholder action. Given that the agents may not be acting in the interests of beneficial investors, so the argument goes, there is reason to limit the power of the tools given to those agents lest they use the tools in ways that are counterproductive to the interests of their beneficial investors. However, our analysis of the agency problems of institutional investors identifies a clear direction in which their stewardship decisions deviate from those that are optimal for their beneficial investors: investment managers can be expected to underutilize the tools they have to engage with corporate managers.

Thus, notwithstanding the imperfections of investment managers as agents for their beneficial investors, there is little basis for concerns that institutional investors will interfere excessively with the actions of corporate managers. Accordingly, there is no reason to weaken shareholder rights or impede shareholder action based on such concerns. An understanding of the agency problems of institutional investors leads to the conclusion that modern corporations do not suffer from too much shareholder intervention, but rather from too little.

- The authors are grateful to Matthew Bodie, Robert Clark, John Coates, Stephen Davis, Einer Elhauge, Jesse Fried, Mark Gertler, Gordon Hanson, Kobi Kastiel, Reinier Kraakman, Enrico Moretti, Mark Roe, Robert Sitkoff, Holger Spamann, Timothy Taylor, and participants in three Harvard seminars and the American Law and Economics Association Annual Meeting for valuable suggestions; to David Mao and Gregory Shill for excellent research assistance; and to Harvard Law School for financial support.

\section{References}

Admati, Anat R., and Paul Pfleiderer. 2009. "The 'Wall Street Walk' and Shareholder Activism: Exit as a Form of Voice." Review of Financial Studies 22(7): 2645-85.

Aghion, Philippe, John Van Reenen, and Luigi Zingales. 2013. "Innovation and Institutional Ownership." American Economic Review 103(1): 277-304.

Ashraf, Rasha, Narayanan Jayaraman, and Harley E. Ryan Jr. 2012. "Do Pension-Related Business Ties Influence Mutual Fund Proxy Voting? Evidence from Shareholder Proposals on Executive Compensation." Journal of Financial and
Quantitative Analysis 47(3): 567-88.

Azar, José, Sahil Raina, and Martin C. Schmalz. 2016. "Ultimate Ownership and Bank Competition.” Available at SSRN: https:/ / papers.ssrn.com/ abstract=2710252.

Azar, José, Martin C. Schmalz, and Isabel Tecu. 2017. "Anti-Competitive Effects of Common Ownership." Available at SSRN: https://papers. ssrn.com/abstract=2427345.

Bainbridge, Stephen M. 2006. "Director Primacy and Shareholder Disempowerment." Harvard Law Review 119(6): 1735-58.

Bebchuk, Lucian A. 2013. "The Myth that 
Insulating Boards Serves Long-Term Value Essay." Columbia Law Review 113(6): 1637-94.

Bebchuk, Lucian A., Alon Brav, and Wei Jiang. 2015. "The Long-Term Effects of Hedge Fund Activism." Columbia Law Review 115(5): 1085-155.

Bebchuk, Lucian A., Alon Brav, Wei Jiang, and Thomas Keusch. 2017. "Dancing with Activists." Available at SSRN: https://papers.ssrn.com/ abstract=2948869.

Bebchuk, Lucian A., Alma Cohen, and Scott Hirst. 2017. "The Under-Supply of Shareholder Engagement." Unpublished.

- Bebchuk, Lucian A., Alma Cohen, and Charles C. Y. Wang. 2013. "Learning and the Disappearing Association between Governance and Returns." Journal of Financial Economics 108(2): 323-48.

Bebchuk, Lucian A., and Robert J. Jackson Jr. 2012. "The Law and Economics of Blockholder Disclosure." Harvard Business Law Review 2: 39-60.

Bebchuk, Lucian A., and Zvika Neeman. 2010. "Investor Protection and Interest Group Politics." Review of Financial Studies 23(3): 1089-119.

Berle, Adolf A., and Gardiner C. Means. 1932. The Modern Corporation and Private Property. New York: Macmillan.

Board of Governors of the Federal Reserve System. 2016. "Financial Accounts of the United States: Flow of Funds, Balance Sheets, and Integrated Macroeconomic Accounts, Z.1." https:// www.federalreserve.gov/releases/z1/current/ (accessed April 15, 2017).

Brav, Alon, Amil Dasgupta, and Richmond D. Mathews. 2016. "Wolf Pack Activism." Available at SSRN: https: / papers.ssrn.com/abstract=2840704.

Brav, Alon, Wei Jiang, Frank Partnoy, and Randall Thomas. 2008. "Hedge Fund Activism, Corporate Governance, and Firm Performance." Journal of Finance 63(4): 1729-75.

Clark, Cynthia E., and Harry J. Bus Van Buren.

2013. "Compound Conflicts of Interest in the US Proxy System.” Journal of Business Ethics 116(2): 355-71.

Coates, John C. IV, and R. Glenn Hubbard. 2007. "Competition in the Mutual Fund Industry: Evidence and Implications for Policy." Journal of Corporation Law 33(1): 151-222.

Coffee, John C. Jr., and Darius Palia. 2015. The Wolf at the Door: The Impact of Hedge Fund Activism on Corporate Governance. Boston: Now Publishers Inc.

Collins, Sean, Sarah Holden, James Duvall, and Elena Barone Chism. 2016. "The Economics of Providing 401(k) Plans: Services, Fees, and Expenses, 2015." ICI Research Perspective 22(4): 1-31.

Council of Experts Concerning the Japanese Version of the Stewardship Code. 2014. Principles for Responsible Institutional Investors. Tokyo, Japan: Financial Services Agency.

Cremers, K. J. Martijn, and Antti Petajisto. 2009. "How Active Is Your Fund Manager? A New Measure that Predicts Performance." Review of Financial Studies 22(9): 3329-65.

Crvijanović, Dragana, Amil Dasgupta, and Konstantinos E. Zachariadis. 2016. "Ties that Bind: How Business Connections Affect Mutual Fund Activism.” Journal of Finance 71(6): 2933-66.

Davis, Gerald F., and E. Han Kim. 2007. "Business Ties and Proxy Voting by Mutual Funds." Journal of Financial Economics 85(2): 552-70.

Demsetz, Harold. 1983. "The Structure of Ownership and the Theory of the Firm." Journal of Law and Economics 26(2): 375-90.

Diamond, Randy. 2016. "Established Firms Keep Lion's Share of Business." Pensions and Investments, November 14. http://www.pionline. com/article/20161114/PRINT/311149993/ established-firms-keep-lions-share-of-business.

Elhauge, Einer. 2016. "Horizontal Shareholding." Harvard Law Review 129(5): 1267-317.

FactSet Research Systems. No date. FactSet Ownership database. https://www.factset.com/ data/company_data/ownership.

Financial Reporting Council. 2012. UK Stewardship Code. London: Financial Reporting Council.

Fink, Laurence D. 2015. Text of Letter Sent to Chairmen/CEOs Asking Them to Focus on Delivering Long-Term Value. New York: BlackRock.

-French, Kenneth R. 2008. "Presidential Address: The Cost of Active Investing." Journal of Finance 63(4): 1537-73.

Gantchev, Nickolay. 2013. "The Costs of Shareholder Activism: Evidence from a Sequential Decision Model." Journal of Financial Economics 107(3): 610-31.

Gilson, Ronald J., and Jeffrey N. Gordon. 2013. "The Agency Costs of Agency Capitalism: Activist Investors and the Revaluation of Governance Rights." Columbia Law Review 113(4): 863-928.

Grossman, Sanford J., and Oliver D. Hart. 1980. "Takeover Bids, The Free Rider Problem, and the Theory of the Corporation." Bell Journal of Economics 11(1): 42-64.

Hartzell, Jay C., and Laura T. Starks. 2003. "Institutional Investors and Executive Compensation.” Journal of Finance 58(6): 2351-74.

Hirst, Scott. 2016. "Social Responsibility Resolutions." Available at SSRN: https://papers.ssrn. com/abstract=2773367.

Investment Company Institute. 2016. 2016 Investment Company Fact Book. Washington, DC: Investment Company Institute.

Ke, Bin, Kathy R. Petroni, and Yong Yu. 2008. "The Effect of Regulation FD on Transient 
Institutional Investors' Trading Behavior.” Journal of Accounting Research 46(4): 853-83.

Krouse, Sarah, David Benoit, and Tom McGinty. 2016. "Meet the New Corporate Power Brokers: Passive Investors." Wall Street Journal, October 24.

Lipton, Martin. 2014. "Current Thoughts about Activism, Revisited." Harvard Law School Forum on Corporate Governance and Financial Regulation, April 8. https://corpgov.law.harvard.edu/2014/04/08/ current-thoughts-about-activism-revisited/.

Lipton, Martin. 2016. "The New Paradigm for Corporate Governance." Harvard Law School Forum on Corporate Governance and Financial Regulation, February 3. https://corpgov.law. harvard.edu/2016/02/03/the-new-paradigm-forcorporate-governance/.

Malenko, Nadya, and Yao Shen. 2016. "The Role of Proxy Advisory Firms: Evidence from a Regression-Discontinuity Design." Review of Financial Studies 29(12): 3394-427.

Manne, H. G. 1965. "Mergers and the Market for Corporate Control." Journal of Political Economy 73(2): 110-20.

McNabb, Bill. 2015. "Investors: Getting to Know You and Your Governance." The Corporate Board, March-April.

Oey, Patricia, and Christina West. 2016. Average Fund Costs Continued to Decline in 2015 But Investors Are Not Necessarily Paying Less. Morningstar Manager Research.

Office of the Superintendent of Financial
Institutions Canada. 2013. Corporate Governance Guideline. Ottawa: Office of the Superintendent of Financial Institutions Canada.

Posner, Eric A., Fiona M. Scott Morton, and E. Glen Weyl. 2016. "A Proposal to Limit the Anti-Competitive Power of Institutional Investors." Available at SSRN: https://papers.ssrn.com/ abstract $=2872754$.

Rock, Edward B., and Daniel L. Rubinfeld. 2017. "Defusing the Antitrust Threat to Institutional Investor Involvement in Corporate Governance." Available at SSRN: https://papers. ssrn.com/abstract=2925855.

-Shleifer, Andrei, and Robert W. Vishny. 1986. "Large Shareholders and Corporate Control." Journal of Political Economy 94(3): 461-88.

-Sirri, Erik R., and Peter Tufano. 1998. "Costly Search and Mutual Fund Flows." Journal of Finance 53(5): 1589-622.

Strine, Leo E. Jr. 2014. "Can We Do Better by Ordinary Investors? A Pragmatic Reaction to the Dueling Ideological Mythologists of Corporate Law Essay." Columbia Law Review 114(2): 449-502.

Tergesen, Anne, and Jason Zweig. 2016. "The Dying Business of Picking Stocks." Wall Street Journal, October 17. http:/ / www.wsj.com/articles/ the-dying-business-of-picking-stocks-1476714749.

Tonello, Matteo, and Stephan Rahim Rabimov. 2010. "The 2010 Institutional Investment Report: Trends in Asset Allocation and Portfolio Composition." Available at SSRN: https:/ / papers.ssrn.com/ abstract=1707512. 